\title{
Et mord i Kastrup 1814 og morderens henrettelse
}

\author{
Af Frode Gribsvad.
}

Lørdag morgen den 24. september 1814 if $\phi$ rte skræder Hans Tychsen i Kastrup sig sine bedste klæder, blå kjole, rơd rest, blå lange bukser, støvler og en rund sort filthat med et smalt silkebånd og spænde på pulden. Han tog sin lille, med rør omvundne stok $\mathrm{i}$ hånden og begav sig kl. 7 på vej til Haderslev for at få ordnet de nфdvendige papirer, så at han. kunne holde hryllup med Tielluf S $\emptyset$ nnichsens 38-årige enke Anna Margretha. Han mente, at han måske kom tilbage natten til søndag, men det kunne også godt være, at han først kom om mandagen. Han kom hverken tilbage søndagen eller mandagen, og om tirsdagen fandtes hans lig ilde tilredt, kastet ind $i$ den indre digegrøft på Kastrup mark og tildækket med græs. Det er tydeligt, at han var bleven myrdet.

Af de afholdte forh $\phi \mathbf{r}$ fremgik det, at han lordag aften mellem kl. 7 og 8 var kommen ind i Gabøl kro, hvor han traf en gammel skolekammerat, Jens Aalkier. De opfriskede gamle erindringer, og Hans Tychsen besluttede sig til at blive i kroen om natten og trak sine st $\varnothing$ vler af. Henimod kl. 11 kom en fremmed mand ind, som sagde, at han var pjaltekræmmer og kaldte sig Anders korporal eller Anders dannebrogsmand. Han fortalte, at han havde været underofficer ved fynske regiments 3. kompagni og var dannebrogsmand. Han havde da også et rødt bånd fæstet på trøjen med knapnåle. Forøvrigt beskrives han som middelmådig

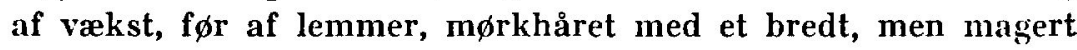
ansigt. Han havde en kort trøje på med små runde blanke knapper, hjemmevævet tøj eller tosel,*) hvid soldatervest, en sort

*) d. e. toskaffet hvergarn med linned rending og ulden islzet. 
silkeklud om halsen med et hvidt klæde under og en gammel sort filthat. Det lykkedes ham at få prakket Hans Tychsen en pibe på for 2 mark 8 skilling, hvorefter de drak lidk $\phi b$ hver for 1 sk. brændevin og et glas $\varnothing$ l. Så ville pjaltekræmmeren k $\emptyset$ be Hans Tychsens s $\varnothing$ lvur, men de kunne ikke blive enige derom. Kromanden opfordrede dem flere gange til at gå til sengs, men nu ville pjaltekræmmeren gå til Kastrup kro, hvor han foregav, at hans kone ventede ham, og han opfordrede Hans Tychsen til at gå med. De fik deres st $\varnothing v$ ler på og begav sig kl. 2-3 på vej.

Krokonen i Kastrup kunne oplyse, at pjaltekræmmeren havde logeret i kroen natten mellem fredag og lørdag. Lørdag morgen var han gået bort ad Haderslev til, hvor han sagde han ville træffe sin kone. Forinden han gik, fæstede han et afbleget rødt silkebånd på sin trøje, for at man skulle kunne se, at han var dannebrogsmand. Søndag morgen kom han igen. Han betalte pigen 18 sk., som han var bleven skyldig for logi og fortæring. Hun lagde mærke til, at han havde en anden hat på, end han havde haft den foregående dag, og da hun fik forevist en gammel hat, der var fundet ved Hans Tychsens lig, genkendte hun $i$ den pjaltekræmmerens hat. Han lejede nu krokonens s $\phi \mathrm{n}$ til at k $\phi$ re sig til Skallebæk m $\varnothing$ lle for 36 sk. Cornelius Giesemanns tjenestepige kørte med. I Gjelsbro mølle havde pjaltekræmmeren og pigen drukket kaffe. Kræmmeren ville, at karlen skulle have en punch, men møllerkonen befriede ham derfor. Da de nåede Skallebæk mølle, ville pjaltekræmmeren have karlen til at $\mathrm{k} \phi \mathbf{r e}$ dem til Ribe, hvorfor han betalte 1 mark. I møllen kom der to karle med på vognen. Undervejs solgte pjaltekræmmeren et ur til den ene af karlene for $7 \mathrm{rdl}$. Det svarede ganske til beskrivelsen af Hans Tychsens s $\varnothing l v u r$. Pjaltekræmmeren blev kørt til Peter Greisen i Ribe, hvor han bestilte logi.

Der kunne herefter ikke være tvivl om, at pjaltekræmmeren var morderen. Den 1. oktober blev derfor kromanden i Gab $\phi$ l, Jes Lauritzen, og sandemand Anders Hansen i Gram sendt ud for at opspore ham. I Ribe mente man, at han derfra havde agtet sig til Varde, og de sporede ham også til en kirkeby sydøst for Varde, men ikke videre, hvorfor de efter 4 dages fraværelse vendte hjem med uforrettet sag. Ved fynske regiment fik man 
oplyst, at den efters $\varnothing$ gte antagelig var en musketer Anders (eller

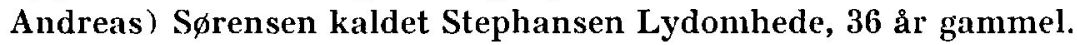
Der blev nu udlovet $160 \mathrm{rdl}$. s $\phi 1 \mathrm{l}$ for oplysninger, der f $\varnothing \mathrm{rte}$ til hans pågribelse. I det udsendte signalement siges, at han havde et ondskabsfuldt ansigt, og at han kunne tale godt for sig. Hans modersmål var dansk, men han kunne måske også tale lidt tysk. Han havde varet 2 gange i Viborg tugthus, for han blev soldat. Da man i Husum havde arresteret en person, som man mente måske kunne være morderen, blev kromanden i Gab $\emptyset 1$ og krokonens s $\phi$ fra Kastrup i februar 1815 sendt derned for at konstatere, om det var den mistænkte. Efter at have været borte i 6 dage kom de tilbage med den besked, at det ikke var den eftersøgte.

Imidlertid viste det sig, at en i Viborg anholdt person var den efterlyste. Han blev sendt til Haderslev og indsat i rådhusarresten her. Herredsfoged, justitsråd Langreuter i Haderslev fik som birkedommer for Gram og Nybøl godser af overretten overdraget sagen imod ham, og den 19. marts kunne han meddele godsinspekt $\varnothing \mathbf{r}$ Lorenzen på Gram, at den forstokkede Anders Lydomhede havde tilstået mordet. Der skulle dog finde en separat-inkvisition med fiskal og defensor sted, så at sagen trak $i$ langdrag. Imidlertid lykkedes det fangen at få fat $i$ en fil og et stemmejern af et kvindemenneske, der skulle transporteres fra Flensborg til Jylland og undervejs var indsat i fangslet i Haderslev, og natten til den 25. maj br $\varnothing d$ han ud af fængslet og flygtede. Friheden varede dog ikke så længe, idet han efter en uges forl $\phi b$ blev fanget ved Vejle og bragt tilbage til arresten $i$ Haderslev, hvor han herefter blev bevogtet dag og nat af 3 eller 4 mænd og med lys i arresten døgnet igennem. Det forekom dog godsinspektøren for kostbart, og siden blev da også vagten indskrænket til 2 mand.

Først den 12. februar 1856 blev dommen forkyndt på rådhuset i Haderslev. Den lød på, at morderen skulle halshugges, hovedet sættes på en pæl og kroppen lægges på hjul. Da Langreuter kom fra domsafsigelsen, skrev han til godsinspekt $\varnothing \mathbf{r}$ Lorenzen: Karlen er en afsky for menneskeheden. Han har ingen følelse eller i hvert fald kun en djævelsk. Man kan ikke med 
tunger udsige, hvor fræk han opfører sig. Han forsikrede, at han ikke ville omvende sig, selv om den herre Kristus selv kom.

Allerede inden dommen var falden, havde man begyndt at g $\varnothing$ re forberedelse til henrettelsen. Man havde således forh $\varnothing r t$ om prisen hos flere skarprettere. St $\varnothing$ ckler i Sønderborg skulle have $8 \mathrm{rdl}$. courant eller 12 rbd. $76 \mathrm{sk}$. s $\phi l v$ for at hugge hovedet af med $\emptyset \mathrm{kse}$ og 14 rdl. cour. ( 22 rbd. 38 sk. s $\emptyset \mathrm{lv}$ ) for at slå arme og ben i stykker på hjulet og for rejsen frem og tilbage samt fortæring 40 rdl. cour. ( 64 rbd.). Desuden skulle han have en assistent og en karl til at sætte hovedet på pæl, og 2 karle når kroppen skulle lægges på hjul. Skarpretteren i Odense forlangte 10 specier for at afhugge hovedet og 1 specie daglig $i$ diætpenge og fri befordring frem og tilbage. Det blev imidlertid skarpretteren i T $\phi$ nder, der også hed St $\varnothing c k l e r$, som fik forretningen.

Den 25. februar blev det $i$ fængslet forkyndt for fangen, at han skulle henrettes den 2. marts på retterstedet i Gram. Dagen f $\varnothing \mathrm{r}$ blev han transporteret fra Haderslev til Gram under militær eskorte, hvad der sikkert har vakt opsigt, hvor de kom frem. Ankommen til Gram blev han anbragt i fængslet der, og der bler sat vagt til at passe på ham.

Skarpretteren var kommen til Gram allerede den 29. februar henimod aften sammen med en assistent og karle, medbringende $\phi \mathrm{kse}$, blok og nagler for at træffe forberedelserne. På en $h \phi j$ i nærheden af post- og landevejen mellem Gram og Ka-

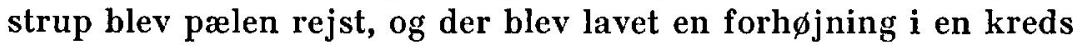
omkring den, $1 \frac{1}{2}$ alen $h \phi j$, nemlig 1 alen jord og $1 / 2$ alen grus $0 g$ sand, der skulle stampes, så at den blev fast og hård at stå og gå på. Foruden den jord og sand, der krævedes til forhøjningen, skulle der tilkøres 3 læs gulvsand. Arbejdet blev bortliciteret til den lavestbydende $-7 \mathrm{rdl}$. 36 sk. courant - og skulle udføres under tilsyn af sandemand Hans Lauritzen.

L $\phi$ rdag den 2. marts kl. 11 om formiddagen blev fangen f $\phi r t$ fra arresten til retterstedet under bevogtning og militær eskorte. I en vogn derefter kørte pastor Lautrup fra Haderslev, der, efter at dommen var bleven forkyndt fangen, utrættelig havde bes $\emptyset \mathrm{gt}$ ham i fængslet, og pastor Møller fra Fole. I en særlig vogn fulgte justitsråd Langreuter. Foran det hele optog red godsinspektør 
Lorenzen og 4 sandemænd, medens 4 andre sandemænd, der red tæt bagefter justitsrådens vogn, sluttede toget. Retterstedet var omgivet af en kreds af bønder, der blev beskyttet af nilitær imod folkemængden, der strømmede til og trængte på for at få så meget at se af skuespillet som muligt. På selve retterpladsen var pæl, hjul og stige rejst. Lænkerne blev nu taget af fangen og hans hænder bundet på ryggen, hvorefter han ledsaget af præsterne blev f $\varnothing$ rt ind på pladsen. Justitsråden oplæste dødsdommen, og efter at fangen havde bedt en b $\not n$, lagde han hovedet på blokken, og idet skarpretter St $\varnothing$ ckler fra Sønderborg, der assisterede, holdt hovedet fast ved håret, faldt det kl. $11_{1 / 4}^{3 / 4}$ for et eneste hug, ført af skarpretter Støckler fra T $\phi$ nder. Karlene satte derefter hovedet på pælen, og kroppen blev radbrækket på hjulet. Således, beretter Lorenzen, blev denne henrettelse fuldført med anstand og ro i overværelse af en stor folkemængde.

Tilbage stod at få regnskabet gjort op over, hvad hele mordog henrettelsessagen havde kostet. Mændene, der var sendt ud for at opspore morderen, skulle have betaling, fangens ophold i arresten i Haderslev kostede ikke mindre end 417 rdl. 42 sk. courant. Skarpretteren fik for sig selv, assistent og karl, kørsel og diæter medregnet, 80 rdl. cour. Borgmester Lindenhan i Haderslev fik 62 rdl. cour. som defensor, sagf $\varnothing$ rer Knudsen 101 rdl. 40 sk. cour. som anklager. Alt ialt bel $\phi b$ udgifterne sig til 778 rdl. 27 sk. cour., så nogen billig historie var sådan en sag ikke - og mordet synes begået for et sølvurs og en hats skyld!

Kilde: Gram godsarkiv: Sager vedr. drab, vold, gade- og værtshusuorden. 1715-1847. 